\title{
Isolasi Bakteri Rhizosfer Penghasil Antimikroba Tanah Disekitaran Akar Tanaman Jeruk Nipis (Citrus aurantifolia Swingle)
}

\section{Rusman $^{1 *}$, Yasnidar'2, Risman ${ }^{3}$}

1 Universitas Islam Makassar,Farmasi,Makassar,Indonesia.

2 Universitas Islam Makassar,Farmasi,Makassar,Indonesia.

3 Universitas Islam Makassar,Farmasi,Makassar,Indonesia.

\section{DOI : https://doi.org/10.29303/sjp.v1i2.39}

\section{Article Info}

Received : 2020-08-08

Revised : 2020-09-28

Accepted : 2020-09-28

\begin{abstract}
Abstrak: Isolation of rhizosphere bacteria producing antimicrobial from soil round the roots of the lime plant (Citrus aurantifolia Swingle). This study aims to obtain rhizosphere bacterial isolates originating from the soil around the roots of the Lime Plant (citrus aurantifolia Swingle) which can be used as antimicrobials. The soil was taken from around the roots of the Lime plant and then diluted with dilutions of 10-1, 10-2, 10-3 to 10-5 dilution, then poured on NA media containing test microbes. The resulting isolates were then purified and coded JS-1, JS-2, JS-3. Microscopic examination results added 2 gramnegative bacterial isolates namely JS- 1 and JS-3, while 1 gram-positive bacterial isolate was JS-2. The resulting isolate was then fermented with NB medium which produced supernatant and biomass, the supernatant was tested antimicrobial which produced active compounds of rhizosphere bacteria (JS-1 and JS-3) from the root soil of the Lime plant have the ability as an antimicrobial activity against Staphylococcus aureus, Escherichia Candida albicans coli and fungal test
\end{abstract}

Keywords: Rhizosfer bacteria, soil around lime root, antimicrobial

Citation: Rusman, Yasnidar, Risman. (2020). Isolasi Bakteri Rhizosfer Penghasil Antimikroba Tanah Disekitaran Akar Tanaman Jeruk Nipis (Citrus aurantifolia Swingle). Sasambo Journal of Pharmacy, 1(2), 46-50. doi: https://doi.org/10.29303/sjp.v1i2.39

\section{Pendahuluan}

Bakteri yang hidup diarea sekitaran akar tanaman disebut sebagai bakteri rhizosfer. Hidup simbiosis mutualisme dengan tumbuhan yaitu hidup yang saling berdampingan dan tidak saling merugikan, bakteri ini banyak digunakan sebagi antimikroba dan antibiotik dalam medis.Tanah rhizosfer merupakan bagian tanah yang berada di sekitar perakaran tanaman. Populasi mikroorganisme di rhizosfer umumnya lebih banyak dan beragam dibandingkan pada tanah nonrhizosfer. Aktivitas mikroorganisme rhizosfer dipengaruhi oleh eksudat yang dihasilkan oleh perakaran tanaman. Beberapa mikroorganisme rhizosfer berperan dalam siklus hara dan proses pembentukan tanah, pertumbuhan tanaman, mempengaruhi aktivitas mikroorgandisme, serta sebagai pengendali hayati terhadap patogen akar.
(Simatupang, 2008 dalam Retno Prayudyaningsih, 2015).

Bakteri rhizosfer yang banyak ditemukan dan digunakan sebagai antimikroba yaitu bakteri Streptomyces, Bakteri Streptomyces merupakan bakteri gram positif yang terdapat didalam tanah,serta pada tumbuhan yang membusuk. Streptomyces bertanggung jawab pada metabolisme banyak senyawa berbeda meliputi gula, alkohol, asam amino dan senyawa aromatik dengan memproduksi enzim hidrolitik ekstraseluler. Streptomyces digunakan untuk kepentingan kesehatan dan industri karena mampu menghasilkan antibiotik. Sebagian besar telah diterima secara luas sebagai salah satu komponen antimikroba. (Aghighi et al., 2004 dalam Oktalia, 2009).

Mikroorganisme yang dapat menghambat pertumbuhan mikroorganisme lainnya disebut dengan Antimikroba sedangkan zat atau senyawa metabolit 
yang dihasilkan oleh mikroorganisme yang dapat menghambat atau membunuh pertumbuhan mikroorganisme disebut antibiotik.(herlina,dkk.,2013)

Penelitian lainya telah dilakukan untuk membuktikan secara ilmiah bahwa daun jeruk nipis dapat digunakan sebagai antipiretik (Widowati Amelia Kartika, 2011). Pengujian menunjukan ekstrak methanol daun jeruk nipis menunjukan yang memberikan aktivitas senyawa antimikroba (Neshia frisennia, 2010). Pengujian selanjutnya yaitu uji daya hambat air perasan buah jeruk nipis (Citrus aurantifolia S.) terhadap bakteri Staphylococcus aureus yang menunjukan semakin tinggi konsentrasi maka semakin tinggi pula daya hambat terhadap bakteri Staphylococcus aureus (Rasak Abdul, 2013).

\section{Metode}

\section{Bahan dan alat}

Bahan yang digunakan dalam penelitian ini adalah tanah Rhizosfer Akar jeruk nipis, Aquadest steril,bakteri Escherichia coli, bakteri Staphylococcus aureus, jamur Candida albicans medium NA (Nutrient Agar), medium PDA (Potato Dextrose Agar), medium PDB (Potato Dextrose Broth), $\mathrm{NaCl}$ fisiologis $(\mathrm{NaCl}$ 0,9\%), kertas Cakram. Alat-alat yang digunakan dalam penelitian ini adalah autoklaf, cawan petri, inkubator, jarum Ose, kotak Vaksin, Laminar Air Flow (LAF) miskroskop, sentrifuge, timbangan analitik

Pembuatan suspense sampel

Sampel tanah ditimbang 1 gram lalu dimasukkan ke dalam botol pengencer dan dicukupkan dengan Air suling steril hingga $10 \mathrm{ml}$ pengenceran 10-1. Suspensi sampel dari pengenceran $10^{-1}$ kemudian dibuat pengenceran $10^{-2}, 10^{-3}$ sampai pada pengenceran $10^{-5}$.

\section{Pembiakan mikroba tanah}

Suspensi sampel dari setiap pengenceran diambil $1 \mathrm{ml}$ secara aseptis, kemudian dimasukkan ke dalam cawan petri, lalu ditambahkan medium Nutrien agar (NA) untuk bakteri dan medium Potato Dextrosa Agar (PDA) untuk jamur dan dihomogenkan. kemudian diinkubasi pada suhu $37^{\circ} \mathrm{C}$ selama $1 \times 24$ jam untuk bakteri (NA) dan untuk jamur (PDA) selama $3 \mathrm{x}$ 24 jam

\section{Fermentasi Biakan Murni}

Koloni biakan murni diambil 1 ose, diinokulasikan pada medium NA dalam Erlenmeyer 50 $\mathrm{ml}$, lalu diinkubasi pada suhu $37^{\circ} \mathrm{C}$ selama $1 \times 24$ jam, kemudian disuspensikan dengan $2 \mathrm{ml}$ larutan $\mathrm{NaCl}$ fisiologis dan diinokulasikan dalam $10 \mathrm{ml}$ medium pembenihan cair NB, Inokulum sebanyak $2 \mathrm{ml}$, dipipet dan dimasukkan ke dalam tabung reaksi yang berisi 10 $\mathrm{ml}$ medium cair, NB diinkubasi pada suhu kamar selama 1×24 jam dan dikocok menggunakan shaker dengan kecepatan $200 \mathrm{rpm}$ selama 1×24 jam. Setelah selesai masing-masing medium disentrifuge dengan kecepatan $3800 \mathrm{rpm}$ pada suhu $4^{\circ} \mathrm{C}$ selama 2 menit. Supernatant diambil kemudian dilakukan pengujian antimikroba pada bakteri Staphylococcus aureus, bakteri Escherichia coli dan pada jamur Candida albicans

\section{Pengujian aktivitas antimikroba}

Pengujian aktivitas antimikroba dilakukan denga cara difusi agar menggunakan paperdisc. Pada medium Nutrien Agar disuspensi dengan mikroba uji yang sudah diukur serapannya, diinokulasi $20 \mu \mathrm{l}$ suspensi mikroba uji kedalam cawan petri tersebut, lalu dituang $10 \mathrm{ml}$ medium NA, lalu diletakkan dalam cawan petri yang telah berisi medium dan mikroba uji,selanjutnya diinkubasi selama $1 \times 24$ jam pada suhu $37^{\circ} \mathrm{C}$ untuk bakteri dan $3 \times 24$ jam pada suhu $27^{\circ} \mathrm{C}$ untuk jamur kemuadian diamati zona hambat yang terbentuk dengan diameter paperdisc $6 \mathrm{~mm}$.

\section{Identifikasi Mikroba Uji}

a. Pengamatan morfologi secara makroskopik

1) Medium Nutrien Agar,dituang kedalam cawan petri steril sebanyak $10 \mathrm{ml}$, kemudian ditambahkan $1 \mathrm{ml}$ isolat mikroba, dibiarkan memadat, setelah memadat kemudian diinkubasikan pada suhu $37^{\circ} \mathrm{C}$ selama $1 \times 24$ jam. Pengamatan dilakukan dengan melihat bentuk koloni, elevasi, tepi, dan struktur dalam. Dilakukan hal yang sama pada isolat 2,3,4, dan 5.

2) Medium Nutrien Agar,dipipet $10 \mathrm{ml}$ dibiarkan memadat dalam tabung reaksi dengan posisi tegak. Setelah memadat kemudian diinokulasikan isolate mikroba secara tusukan dengan ose lurus, selanjutnya diinkubasikan pada suhu $37^{\circ} \mathrm{C}$, selama $1 \times 24$ jam. Pengamatan dilakukan dengan melihat bentuk koloninya. Dilakukan hal yang sama pada isolat $2,3,4$ dan 5.

3) Medium Nutrien Agar,dipipet $7 \mathrm{ml}$ dalam tabung reaksi kemudian dimiringkan, dibiarkan memadat kemudian diinokulasikan isolat mikroba dengan cara digores dengan ose bulat. Setelah memadat diinkubasikan pada suhu 37 ${ }^{\circ} \mathrm{C}$, selama 1×24 jam. Pengamatan dilakukan dengan melihat bentuk koloninya. Dilakukan hal yang sama pada isolat 2,3,4 dan 5 .

4) Medium Nutrien Broth,dipipet $10 \mathrm{ml}$ dalam tabung reaksi, kemudian diinokulasikan isolat mikroba dengan ose bulat. Setelah memadat diinkubasikan pada autoklaf suhu $37^{\circ} \mathrm{C}$, selama 1×24 jam. Pengamatan dilakukan dengan melihat bentuk koloni, warna dan keadaan permukaannya. Dilakukan hal yang sama pada isolat 2, 3, 4 dan 5 . 
5) Dilakukan identifikasi seperti di atas terhadap isolat jamur menggunakan medium PDA dan NB dengan masa inkubasi selama $3 \times 24$ jam pada suhu kamar.

b. Pengamatan morfologi secara mikroskopik dengan pengecatan Gram

Disiapkan objek gelas dan deck gelas yang telah dibersihkan dan dibebaslemakkan dengan etanol $70 \%$. Dengan ose bulat dibuat film yang tipis pada permukaan objek gelas, kemudian ditambahkan dengan cat A sebanyak 1-2 tetes, didiamkan selama 30 detik lalu dicuci dengan air mengalir dan dikeringkan dengan tissue.

Setelah kering dilakukan perlakuan yang sama seperti pada penambahan cat A secara bergantian mulai dari penambahan cat $B$ (30 detik), cat C (20 detik) dan cat $\mathrm{D}$ (30 detik). Setelah itu, preparat siap untuk diamati di bawah mikroskop. Pengamatan dilakukan dengan melihat bentuk morfologi dan warna isolat bakteri. Warna ungu menunjukkan bakteri Gram positif, sedangkan warna merah menujukkan bakteri Gram negatif.

\section{Hasil dan Pembahasan}

\section{A. Hasil Isolasi Dari Tanah Rhizosfer Jeruk Nipis}

Telah dilakukan penelitian isolasi bakteri rhizosfer dari sampel tanah disekitaran akar tanaman Jeruk Nipis, yang berhasil diisolasi 3 isolat bakteri rhizosfer. Isolasi bakteri rhizosfer dimulai dengan pengenceran sampel mulai dari $10-^{1}$ sampai $10-^{-5}$. Hal ini dimaksudkan untuk menurunkan jumlah mikroorganisme agar diperoleh penyebaran koloni yang baik dan tidak mengalami penumpukan. Kolonikoloni yang diisolasi hanya yang memberikan daerah bening tersebut membentuk suatu zat yang dapat mempertahankan hidupnya dari kompetisi nutrient dari koloni-koloni lain disekitarnya sehingga koloni lain tidak dapat tumbuh, hal ini sesuai dengan teori yang kemukakan oleh Wattimena (1989) bahwa mikroba-mikroba penghasil antimikroba membentuk suatu zat yang dapat mempertahankan hidupnya dari kompetisi nutrient pada medium tempat tumbuhnya. hasil pengenceran dituang kedalam cawan petri yang berisi media NA untuk mikroba uji (bakteri Staphylococcus aureus dan Escherichia coli), dan media PDA untuk mikroba uji (jamur Candida albicans) hanya pada pengenceran $10^{-2}$ dan $10^{-3}$ ditemukan mikroba yang memiliki potensi untuk dijadikan isolat.
Tabel 1. Pengamatan mikroorganisme rhizosfer yang memiliki potensi untuk dijadikan isolate

\begin{tabular}{lccc}
\hline Pengenceran & $\begin{array}{c}\text { Staphylococcus } \\
\text { Aureus }\end{array}$ & $\begin{array}{c}\text { Escherichia } \\
\text { coli }\end{array}$ & $\begin{array}{c}\text { Candida } \\
\text { albicans }\end{array}$ \\
\hline $10^{-1}$ & - & - & - \\
$10^{-2}$ & - & + & - \\
$10^{-3}$ & + & - & + \\
$10^{-4}$ & - & - & - \\
$10^{-5}$ & - & - & - \\
\hline
\end{tabular}

Ket : $\quad+=$ Potensi sebagai antimikroba

- = tidak memiliki potensi sebagai antimikroba
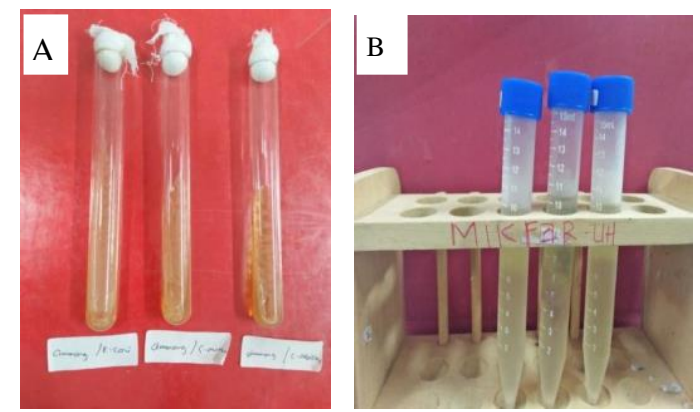

Gambar 1. Foto Stock isolat bakteri Rhizosfer (A) pada media miring, dan (B) adalah foto Hasil senrtifuge.

Isolat bakteri dari Tanah Rhizosfer yang diperoleh ditunjukkan dengan adanya koloni bakteri yang dapat menghambat pertumbuhan bakteri disekitarnya, kemudian diamati bakteri Rhizosfer secara makroskopik (bentuk, dan warna koloni) untuk memperoleh isolate murni. Hasil isolasi tanah sekitaran akar tanaman jeruk nipis diperoleh 3 isolat, dari masing-masing mikroba uji yang memperoleh hanya 1 isolat yang menunjukkan adanya zona hambatan, yang diberi kode JS-1, JS-2, JS-3. Isolat mikroba yang diperoleh dimurnikan dengan cara digoreskan pada media NA baru yang diinkubasi pada suhu $37^{\circ} \mathrm{C}$ selama 24 jam.

Isolat yang telah dianggap murni kemudian dilakukan pengamatan secara mikroskopik, yaitu dengan pengecetan gram. Pengecetan gram pada isolat bakteri Rhizosfer dilakukan untuk mengidentifiklasi bakteri yang diperoleh agar dapat diklasifikan sebagai bakteri gram positif atau bakteri gram negatif. Berdasarkan tabel 3, isolat JS-1 dan JS-3 termasuk kedalam bakteri gram negatif. Gram negatif memiliki dinding sel yang tipis sehingga pada pemerian cat penutup (Safranin) dapat terwarnai. Sedangkan isolat JS-2 termasuk bakteri gram positif 


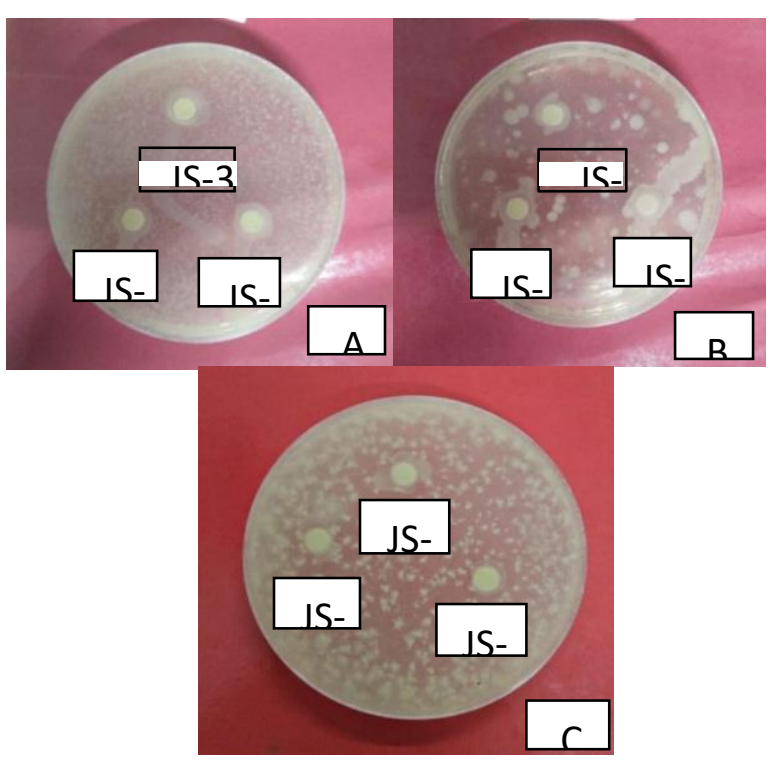

Gambar 2. Foto hasil uji aktivitas Antimikroba, (A) aktivitas isolat JS-1, JS-2, dan JS-3 pada BakteriStaphylococcus aureus, (B) aktivitas isolat JS-1, JS-2 dan JS-3 pada BakteriEscherichia coli, dan (C) aktivitas isolat JS-1, JS-2 dan JS-3 pada Jamur Candida albicans

Gram positif mempunyai kadar lipid dan protein yang rendah sehingga mengalami denaturasi protein pada dinding sel, oleh pencucian dengan alkohol sehingga menjadi keras dan beku, pori-pori mengecil sehingga kompleks Kristal violet dan iodium dipertahankan karena sel bakteri warna biru atau ungu.

Tabel 3. Hasil Pengamatan Mikroskopik Isolat Bakter Tanah Akar Tanaman Jeruk Nipis

\begin{tabular}{ccccc}
\hline \multirow{2}{*}{ No. } & \multirow{2}{*}{$\begin{array}{c}\text { Kode } \\
\text { Isolat }\end{array}$} & \multicolumn{3}{c}{ Mikroskop } \\
\cline { 3 - 5 } & & Warna & Bentuk & Keterangan \\
\hline 1 & JS-1 & Merah & Bulat & Gram negatif \\
2 & JS-2 & Ungu & Bulat & Gram positif \\
3 & JS-3 & Merah & Batang & Gram negatif \\
\hline
\end{tabular}

\section{Fermentasi Dan Pembuatan Stock Pada Bakteri}

Setelah diperoleh isolat murni dilakukan pembuatan bakteri rhizosfer dalam media kultur pada media agar miring sebagai stock. Kemudian dilanjutkan dengan fermentasi menggunakan medium NB yang mengandung. Pengocokan pada fermentasi dilakukan untuk mempercepat pertumbuhan, dan pertumbuhan tersebut lebih homogen dan untuk meminimalkan terjadinya kontaminasi, sistem permentasi yang digunakan adalah sistem batch/tertutup artinya tidak ada penambahan bahan atau pengambilan hasil selama fermentasi berlangsung. Hal ini dikarenakan semua nutrisi yang dibutuhkan mikroorganisme selama pertumbuhan dan pembentukan produk berada dalam satu fermentor, jadi tidak ada penambahan bahan atau pengambilan hasil selama fermentasi berlangsung. Keuntungan sistem ini adalah mudah, sederhana, dan kecil kemungkinan adanya kontaminasi (McNell dan Harvey, 2008). Kemudian hasil fermentasi disentrifuge untuk mendapatkan supernatant dan biomasaa.Supernatant tersebut dilanjutkan pada pengujian antimikroba.

\section{Hasil pengujian Aktivitas}

Cairan fermentasi yang telah disentrifuge dilakukan pengujian aktivitas antimikroba yaitu metode difusi agar dengan menggunakan kertas cakram. Metode ini efektif dan efisien, medium yang digunakan adalah Nutrien Agar (NA) kerena merupakan media biakan yang dibuat dari ekstrak beef, pepton, dan agar, menurut (Radji maksum, 2011) bahwa karbohidrat sangat dibutuhkan oleh bakteri, merupakan substrak utama untuk metabolisme bakteri yang merupakan kandungan dari pepton. Hampir setengah berat kering suatu bakteri merupakan unsur karbon. Karbon dapat ditemukan dalam senyawa karbohidrat, sehingga karbohidrat sangat berperan penting untuk mendukung pertumbuhan bakteri.

Tabel 4. Hasil pengujian aktivitas

\begin{tabular}{|c|c|c|c|c|c|c|}
\hline $\begin{array}{l}\text { I } \\
\text { S }\end{array}$ & \multicolumn{2}{|c|}{$\begin{array}{l}\text { Staphylococus } \\
\text { aureus }\end{array}$} & \multicolumn{2}{|c|}{ Escherichia coli } & \multicolumn{2}{|c|}{$\begin{array}{l}\text { Candida } \\
\text { albicans }\end{array}$} \\
\hline $\begin{array}{l}\mathrm{L} \\
\mathrm{A} \\
\mathrm{T}\end{array}$ & $\begin{array}{l}\text { Zona } \\
\text { hambat }\end{array}$ & Ket. & $\begin{array}{l}\text { Zona } \\
\text { hambat }\end{array}$ & Ket. & $\begin{array}{l}\text { Dia } \\
\text { mete } \\
\mathrm{r}\end{array}$ & Ket. \\
\hline $\begin{array}{l}\text { JS } \\
-1\end{array}$ & $\begin{array}{l}11,31 \\
\mathrm{~mm}\end{array}$ & lemah & $\begin{array}{c}10,92 \\
\mathrm{~mm}\end{array}$ & lemah & $\begin{array}{l}8,13 \\
\mathrm{~mm}\end{array}$ & $\begin{array}{c}\text { Tidak } \\
\text { ada }\end{array}$ \\
\hline $\begin{array}{l}\text { JS } \\
-2\end{array}$ & $\begin{array}{l}11,05 \\
\mathrm{~mm}\end{array}$ & lemah & $\begin{array}{c}10,42 \\
\mathrm{~mm}\end{array}$ & lemah & $\begin{array}{l}8,66 \\
\mathrm{~mm}\end{array}$ & $\begin{array}{c}\text { Tidak } \\
\text { ada }\end{array}$ \\
\hline $\begin{array}{l}\text { JS } \\
-3 \\
\end{array}$ & $\begin{array}{c}10,27 \\
\mathrm{~mm}\end{array}$ & lemah & $\begin{array}{c}12,31 \\
\mathrm{~mm}\end{array}$ & lemah & $\begin{array}{l}9,59 \\
\mathrm{~mm}\end{array}$ & $\begin{array}{c}\text { Tidak } \\
\text { ada }\end{array}$ \\
\hline
\end{tabular}

Tabel 5. Klasifikasi zona hambat menurut greenwood (1995)

\begin{tabular}{cc}
\hline Diameter zona hambat & Respon zona hambat \\
\hline $20 \mathrm{~mm}$ & Kuat \\
$16-20 \mathrm{~mm}$ & Sedang \\
$10-15 \mathrm{~mm}$ & Lemah \\
$<10$ & Tidak ada \\
\hline
\end{tabular}

Hasil pengujian aktivitas antimikroba menunjukkan semua isolat memberikan aktivitas antimikroba terhadap mikroba uji, hal ini ditunjukkan 
karena terdapatnya zona hambatan. Adapun isolat yang menunjukkan aktivitas terhadap antimikroba uji Staphylococus aureus yaitu isolat JS- 1 memberikan daya hambat $11,31 \mathrm{~mm}$, JS-2 membarikan daya hambat $11,05 \mathrm{~mm}$ dan JS-3 memberikan daya hambat 10,27 $\mathrm{mm}$. Isolat untuk mikroba uji Escherichia coli pada isolat JS-1 memberikan daya hambat $10,92 \mathrm{~mm}$, isolat JS-2 memberikan daya hambat 10,42 $\mathrm{mm}$ dan isolat JS-3 memberikan daya hambat $21,31 \mathrm{~mm}$. Isolat JS-1 pada mikroba uji Candida albicans memberikan daya hambat $8,13 \mathrm{~mm}$, isolat JS-2 memberikan daya hambat $8,66 \mathrm{~mm}$ dan isolat JS-3 memberikan daya hambat 9,59 mm. daya hambatan ditujukan dengan menghambat pertumbuhan mikroba lain (memberikan daerah bening disekitarnya), hal ini sesuai dengan teori yang dikemukakan oleh Pelczar (1977) yang menyatakan bahwa mikroba penghasil antibiotik adalah mikroba yang menghasilkan zat-zat dalam jumlah sedikitpun mempunyai daya kegiatan mikroorganisme lain (Riskawati, ddk. 2010).

\section{Kesimpulan}

1. Isolasi bakteri rhizosfer tanah disekitaran Akar tanaman Jeruk Nipis (Citrus aurantifolia Swingle) menghasilkan tiga isolat bakteri rhizosfer murni yang di berikan kode JS-1, JS-2, JS-3.

2. Isolasi bakteri rhizosfer memiliki aktivitas antimikroba terhadap semua mikroba uji.

\section{Daftar Pustaka}

Aslim F. 2014. Daya Hambat Xylitol Terhadap Pertumbuhan Mikroorganisme Rongga Mulut (Streptococcus mutans, Staphylococcus aureus, Dan Candida albicans) Studi In Vitro. Skripsi. Fakultas Kedokteran Gigi Bagian Oral Biologi: Makassar

Biomed, M Maksum Radji. 2010. Buku ajar Mikrobiologi panduan mahasiswa farmasi dan kedokteran. EGC kedokteran: Jakarta.

Djide, M. N. \&Sartini., 2008. Analisis Mikrobiologi Farmasi. Lembaga Penerbitan Unhas (Lephas). Makassar.

Entjang Indan. 2003. Mikrobiologi dan parasitologi. PT Citra Aditia Bakti: Jakarta.

Harti, A. S. 2015. Mikrobiologi Kesehatan. CV. Andi Offset : Yogyakarta.

Herbie Tandi. 2015. Kitab Tanaman berkhasiat Obat 226 Tumbuhan Obat Untuk.Penyembuhan Penyakit dan Kebugaran Tubuh.Octopus Publishing House: Yogyakarta.

Herlina R., Taebe B., Intan S., 2013. Isolasi Fungi Endofit Penghasil Senyawa Antimikroba Dari Daun Cabai Katokkon (Capsicum annuum L var. chinensis) Dan Profil KLT Bioautografi. Fakultas Farmasi Universitas Hasanuddin; Makassar.

Ibrahim J., 2017. Tingkat Cemaran Bakteri Staohylococcus aureus Pada Daging Ayam Yang Dijual Di Pasar Tradisional Makassar. UIN Alauddin Makassar; Makassar.

Oktalia D. A. 2009.Isolasi Streptomyces Dari Rhizosfer Familia Poaceae Yang Berpotensi Menghasilkan Antibiotik Terhadap Staphylococcus aureus.Skripsi.Fakultas farmasi Universitas muhammadiyah Surakarta; Surakarta.

Panagan, A T., 2011.Isolasi Mikroba Penghasil Antibiotika dari Tanah Kampus Unsri Indralaya menggunakan media ekstrak Tanah.Universitas Sriwijaya; Sumatra Selatan.

Pujiati 2014.Isolasi actinomycetes dari tanah kebun Sebagai bahan petunjuk praktikum mikrobiologi. Madiun: Jurnal Florea Volume 1 No. 2: 42-46.

Putra Wikanda Satria. 2013. 68 Buah Ajaib penangkal penyakit. Katahati: Jogjakarta.

Prayudyaningsi.R, dkk. 2015. Mikroorganisme tanah bermanfaat pada rhizosfer tanaman umbi di bawah tegakan hutan rakyat Sulawesi Selatan. Makassar.Volume 1, Nomor 4.:954959.

Prasetyono Dwi Sunnar. 2012. A-Z Daftar tanaman obat ampuh di sekitar kita. Publishing: Yogyakarta.

Rasak, A dkk. 2013. Artikel Penelitian Uji Daya Hambat Air Perasan Buah Jeruk Nipis (Citrus aurantifolia s.) Terhadap Pertumbuhan Bakteri Staphylococcus Aureus Secara In Vitro. Jurnal Kesehatan Andalas. 2 (1) 5-8.

Sulaeman, L. P. 2015. Deteksi Bakteri Escherichia coli Dan Shigella Sp Dalam Telur Balado Serta Resistensinya Terhadap Beberapa Antibiotik.Skripsi. Fakultas Kedokteran Dan Ilmu Kesehatan Universitas Islam Negeri Syarif Hidayatullah: Jakarta.

Wibowo, S. 2013 Herbal Ajaib Tumpas macam-macam penyakit. Pustaka Makmut: Jakarta

Yahya, H. 2016. Pengaruh Air Perasan Buah Jeruk Nipis (Citrus aurantifolia Swingle) Terhadap Hambatan Pertumbuhan Bakteri Enterococcus faecalis Dominan Pada Saluran Akar Secara In Vitro. Skripsi.Fakultas Kedokteran Gigi Universitas Muhammadiyah: Surakarta.

Yusuf, A. 2011.Tingkat Kontaminasi Escherichia coli Pada Susu Segar Di Kawasan Gunung Perak, Kabupaten Sinjai.Skripsi.Fakultas Peternakan Universitas Hasanuddin: Makassar. 